\title{
Confirmation of Cage Effect and Prebiotic Production Potential of a $\beta$-Mannanase, with SBM as Substrate Using Microscopy and Wet Chemistry
}

\author{
L. M. Gomez-Osorio ${ }^{1}$, Hwa Gyun $\mathrm{Oh}^{2} \&$ Jung Jin Lee ${ }^{2}$ \\ ${ }^{1}$ Alura Animal Health and Nutrition, Bogotá, Colombia \\ ${ }^{2}$ CTCBIO Inc., Seoul, South Korea \\ Correspondence: Luis-Miguel Gomez-Osorio, Alura Animal Health and Nutrition, Carrera 129 \# 22b-57 Int 23, \\ Bogotá, Colombia. Tel: 57-320-788-5955. E-mail: lgomez@alura-ahn.com
}

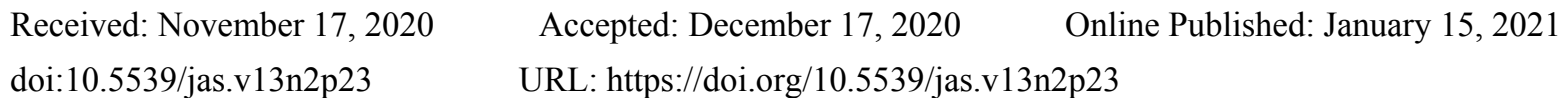

This research is financed by Alura Animal Health and Nutrition and CTCBIO INC.

\begin{abstract}
In vitro assays were carried out to investigate the solubilization of cell walls and generation of mannan oligosaccharides of a b-mannanase-containing commercial product on SBM. Using commercial dosages of the b-mannanase (500 g per ton of feed) cell wall degradation of mannan in SBM cell walls was visualized and an increase in reducing ends $(0.12 \pm 0.02 \mathrm{mg} / \mathrm{mL})$ and the generation of mannan oligosaccharides of degree of polymerization 2 and $4(22.9 \pm 3.2 \mathrm{mg} / \mathrm{L}$ and $398.8 \pm 25.4 \mathrm{mg} / \mathrm{L})$ were also measured using HPLC. Mannan, which is H-bonded to cellulose and xyloglucan, was solubilized using a single monocomponent enzyme, allowing for visualization of the disintegration of the entire SBM cell wall structure. This work is the first of its kind using strictly commercial dosage levels of enzyme for evaluating efficacy of the same microscopically. These data confirm the hypothesis that there most likely is a need for only a single relevant NSP enzyme targeting its specific substrate, independent of the concentration of the latter within the complex polysaccharide matrix in the plant cell wall to experience the beneficial effects of the enzyme both in vitro and in vivo. An analogy to compare our data would be destruction of the foundation (mannan) of a building or a bridge (soybean cell wall) which would inevitably lead to dismantling or demolition the entire building or bridge.
\end{abstract}

Keywords: soybean meal, b-mannanase, mannans, antinutritional factors, microscopy, solubilization of mannan, MOS

\section{Introduction}

Non-starch polysaccharide (NSP) degrading enzymes are added to help increase the metabolizable energy in fiber-containing monogastric diets. Many studies in the past have been conducted to improve the understanding of the mode of action of NSPases or fiber-degrading enzymes for use in animal feed. The three main modes of action postulated are (1) reduction in viscosity (2) destruction of cell walls by solubilization of specific polymers which make up the cell walls to release the starch/protein encapsulated within and (3) Generation of soluble oligosaccharides during cell wall destruction which have prebiotic effects (Bedford, 2018). It has been reported that the addition of NSP-degrading enzymes such as b-mannanases and xylanases improve animal growth performance by improving nutrient digestibility and increasing the levels of good gut bacteria (Mehri et al., 2010; Lan et al., 2017). However, the mechanisms by which NSP-degrading enzymes exert these effects are still under debate. A recent study showed that there was increased ileal expression of MUCIN 2 in pigs fed high-fiber diets with no changes in goblet cell number. Addition of NSP-degrading enzymes to the diet modulated the local immune profile of the ileum, increasing IL-1b expression and concentration and decreasing IL-4, IL-17A and IL-11 concentration (Ferrandis et al., 2018). It is also claimed NSPases can be considered as tools to train the microbiome to be better able to degrade fiber more effectively especially when they are accompanied initially with oligosaccharides. By breaking down the fiber they produce small amounts of oligosaccharides which have prebiotic effect, and they are postulated to play a role in signaling to the gut microbial population present to develop a higher fiber-degrading capacity (Bedford, 2018). 
In this work using a b-mannanase, a NSPase product we have endeavored to study in vitro, where we clarify the two postulated modes of action of NSPases: namely cell wall degradation or decaging effect and generation of prebiotic oligosaccharides. One of the key anti-nutritional factors (ANF) in plant cell walls is b-mannan, an NSP fiber component. It is composed of a backbone of mannose and glucose units in $\beta$-1,4-linkages (Moreira \& Filho, 2008), and may also be linked to galactose residues by $\alpha-1,6$ linkage which increases its water solubility. The mannan structure in SBM is galactomannan having an average galactose to mannose ratio of 1:1.8 (Hsiao et al., 2006). Mannan is H-bonded to cellulose and xyloglucan and its interaction with cellulose resembles that of xyloglucan (Schröder et al., 2009).

One way of trying to understand the positive in vivo effects of NSPases, is to study the effects of the same in vitro. But cell wall breakdown theory with the current published in vitro data is also being challenged (Bedford, 2018). One of the analytical tools used is microscopy to visualize the enzyme's effect on feed substrates and understand cell wall breakdown theory as well as the composition and cell wall architecture of some raw materials (Pedersen et al., 2017). Commercial dosages of enzyme showed very little cell wall degradation (Tervila-Wilo et al., 1996), but cell wall degradation was clearly visualized when very high amounts of enzyme between 100-500X beyond commercial in-vivo dosages were used (Pedersen et al., 2017), which may not be economically relevant or be able to explain good in vivo effects (Le et al., 2013; Pedersen et al., 2017; Ravn et al., 2016). The objective of current study was to use commercially relevant dosages of the current b-mannanase product on SBM and prove that the hypothesis of cell wall degradation is true; to show the effective solubilization/breakdown of cell walls by an NSPase enzyme in vitro and production of oligosaccharides in order to understand positive in vivo results obtained in poultry, pigs and cattle (Ferreira et al., 2016; Kim et al., 2017; Park et al., 2019; Tewoldebrhan et al., 2017).

\section{Materials and Methods}

\subsection{Chemicals}

All chemicals used were from Sigma-Aldrich (USA), mannan oligosaccharides were purchased from Megazyme International, Ireland, antibodies were from Plant Probes, England and Thermo-Fisher Scientific.

\subsubsection{Plant Material}

The compositional analysis of the solvent extracted defatted SBM was as follows: Starch $2.4 \%$, protein $46 \%$, fat $1.8 \%$, fiber $4 \%$, ash $6 \%$.

\subsection{Enzyme Product}

CTCzyme obtained from CTCBio Inc. S. Korea, is a commercial monocomponent $\beta$-mannanase product produced by $B$. subtilis with a declaration of $800,000 \mathrm{U} / \mathrm{kg}$ mannanase. One enzyme unit is defined as generation of $1 \mu$ mole of reducing sugar per min at $\mathrm{pH} 6.0$ and $50{ }^{\circ} \mathrm{C}$ using locust bean gum as substrate.

\subsection{Enzyme Treatment of SBM Before Microscopy}

Samples of SBM were incubated individually at pH 5 either without enzyme (control) or with the addition of either CTCzyme at commercial (1X) or 10X commercial dosages. In short, $1 \mathrm{~g}$ each of SBM samples was incubated with $0.1 \mathrm{M}$ sodium acetate buffer $\mathrm{pH} 5$ alone (control) or commercial $\beta$-mannanase product CTCzyme in the same buffer at $40{ }^{\circ} \mathrm{C}$ for $4 \mathrm{~h}$ with stirring at $500 \mathrm{rpm}$. After incubation, the samples were then centrifuged at $2500 \times \mathrm{g}$ for $10 \mathrm{~min}$. The pellets obtained were washed once with MiliQ water, recentrifuged and dried overnight at $60^{\circ} \mathrm{C}$ and used for microscopy analyses.

\subsection{Embedding and Sectioning}

Controls and enzyme treated SBM pellets were embedded in paraffin. Prior to the embedding procedure, a protocol according to Ravn et al. (2016) was followed whereby the control and enzyme treated SBM samples were first fixed in Karnovsky's fixative, washed progressively in $0.1 \mathrm{M}$ cacodylate buffer $\mathrm{pH} 7.3$ and demineralized water and dehydrated increasingly higher concentrations of ethanol (from 50-99\%) before infiltration in melted paraffin at $60{ }^{\circ} \mathrm{C}$ using Histochoice clearing agent (Sigma-Aldrich). Approximately 7-10 $\mu \mathrm{m}$ thick sections of paraffin-embedded samples were sectioned on a Leica Reichert-Jung 2030 microtome.

\subsection{Immunochemistry for Visualization of Samples Embedded in Paraffin and Staining With Calcofluor}

The procedure was carried out as described in Pedersen et al. (2017). A 5\% skimmed milk solution (from Sigma-Aldrich) in $1 \times$ PBS was used to block the paraffin sectioned SBM samples of control (Incubated with buffer alone) and b-mannanase-treated enzyme product for $1 \mathrm{~h}$. Sections were then washed in PBS buffer followed by incubation for $1 \mathrm{~h}$ with 10-fold dilutions of the rat monoclonal antibody (LM21) diluted in the skimmed milk-PBS buffer solution. Samples were subsequently incubated for $1 \frac{1}{2} \mathrm{~h}$ with anti-rat IgG linked to an 
Alexa-555 fluorophore and washed in PBS buffer. The anti-fading agent Citiflour AF1(Agar Scientific, UK) was used to avoid fluorescence signal from bleaching. A negative control labelling was also carried out using only the secondary antibody. Slides were also stained for 2 minutes with a drop of Calcofluor stain as a counterstain to stain b-glucan linkages such as cellulose and xyloglucan in the presence and absence of LM 21 - the antibody to b-mannan.

\subsection{Confocal Immunofluorescence Microscopy}

A Confocal Laser Scanning Microscope (Olympus, Japan), was used to obtain confocal images of immunolabeled SBM samples. A 20x water-immersion objective was used for all images. An excitation laser line at $561 \mathrm{~nm}$ (green) and an emission spectrum from 590 to $630 \mathrm{~nm}$ designated red in the software was used to monitor the Alexa-555 fluorescein-signal from the immunolabelling. An excitation laser line at $488 \mathrm{~nm}$ (blue) and an emission spectrum from 500 to $540 \mathrm{~nm}$ designated green in the software was used to monitor the autofluorescence from protein globules. For the calcofluor staining, an excitation laser line of $405 \mathrm{~nm}$ and an emission spectrum from $430-480 \mathrm{~nm}$, designated as blue in the software was used to monitor the fluorescence of the cell walls. Multicolor super resolution images in 3 different channels were simultaneously obtained.

\subsection{Enzyme Reaction for Wet Chemistry Analyses}

SBM was used at a concentration of $1 \%$. The experiments were carried out in triplicate. In short, $3 \mathrm{~g}$ of SBM was mixed with $300 \mathrm{~mL}$ of $0.02 \mathrm{M}$ phosphate buffer at $\mathrm{pH} 6.0$ and $300 \mathrm{u} / \mathrm{mL}$ enzyme (commercial dosage) and incubated for a total of 180 mins at $50{ }^{\circ} \mathrm{C}$ with stirring. Samples were taken at several time intervals for reducing end assays and at the end of the reaction for analyses of oligosaccharides. After the incubation time, the reaction mixture was centrifuged, and supernatant were tested for reducing ends and were also run on an HPLC column (SUGAR SP0810, Shodex, Japan) for detection of MOS as described.

\subsection{Reducing ends assay}

DNS assay was carried out using SBM $(1.0 \% \mathrm{w} / \mathrm{v})$ as substrate. SBM was mixed with $20 \mathrm{mM}$ sodium-phosphate buffer (pH 6.0) by stirring constantly at $50{ }^{\circ} \mathrm{C}$. An aliquot of $300 \mathrm{U} / \mathrm{ml}$ enzyme was incubated with the SBM substrate at $50{ }^{\circ} \mathrm{C}$ up to $120 \mathrm{~min}$. The reaction was stopped by the addition of DNS reagent and subsequent boiling for $5 \mathrm{~min}$ and reducing sugar was measured at $540 \mathrm{~nm}$ against the blank. The reducing sugars released were then determined against a standard curve obtained with mannose (Sigma-Aldrich) (Miller, 1959; Garriga et al., 2017).

\subsection{HPLC}

Mannan oligosaccharide concentrations were analyzed by high performance liquid chromatography with evaporative light scattering detector (HPLC-ELSD) using an Agilent 1200 system (Agilent, CA) with SUGAR SP0810 analytical column $(8 \times 300 \mathrm{~mm})$ at $80^{\circ} \mathrm{C}$. For analysis of oligosaccharides, deionized water was used as an eluent. The eluent flow was kept at $1.0 \mathrm{~mL} / \mathrm{min}$. Quantification was carried out using external standards: mannan oligosaccharides purchased from Megazyme, Ireland. Amounts were expressed as milligrams per liter $(\mathrm{mg} / \mathrm{L})$. Data were collected and analyzed with the program ChemStation software (Agilent, CA).

\subsection{Statistical Analysis}

All statiscal analyses of the sugar ends data were done in Excel (Microsoft Office, 2016) by T-test group comparison, one tailed test. Visualization of enzyme by microscopy was only observational and was done in triplicate.

\section{Results}

\subsection{Microscopy}

Images were recorded with a confocal laser scanning microscope (CLSM) displaying the Alexa-555 fluorescein signal in red, protein autofluorescence signal is green and calcofluor signal as blue. Calcofluor is known to emit fluorescence when binding to b-glucan linkages such as cellulose (Herrera-Ubaldo \& de Folter, 2018) and xyloglucan. Immunofluorescence labelling with monoclonal antibody LM21 b-mannan (Marcus et al., 2010) bound to the cell wall lining overlapping the blue color showing that b-mannan is very closely linked to the b-glucan linkages cellulose and xyloglucan the major NSP in SBM (Figure 1A). After enzyme treatment, the monoclonal antibody signal was significantly reduced (Figure 1B), or not detected (Figure 1C), compared to samples incubated in acetate buffer alone (Figure 1A). A notable loosening of cell walls can be seen on enzyme treatment making the protein more visible (Figures $1 \mathrm{~B}$ and $1 \mathrm{C}$ ). 

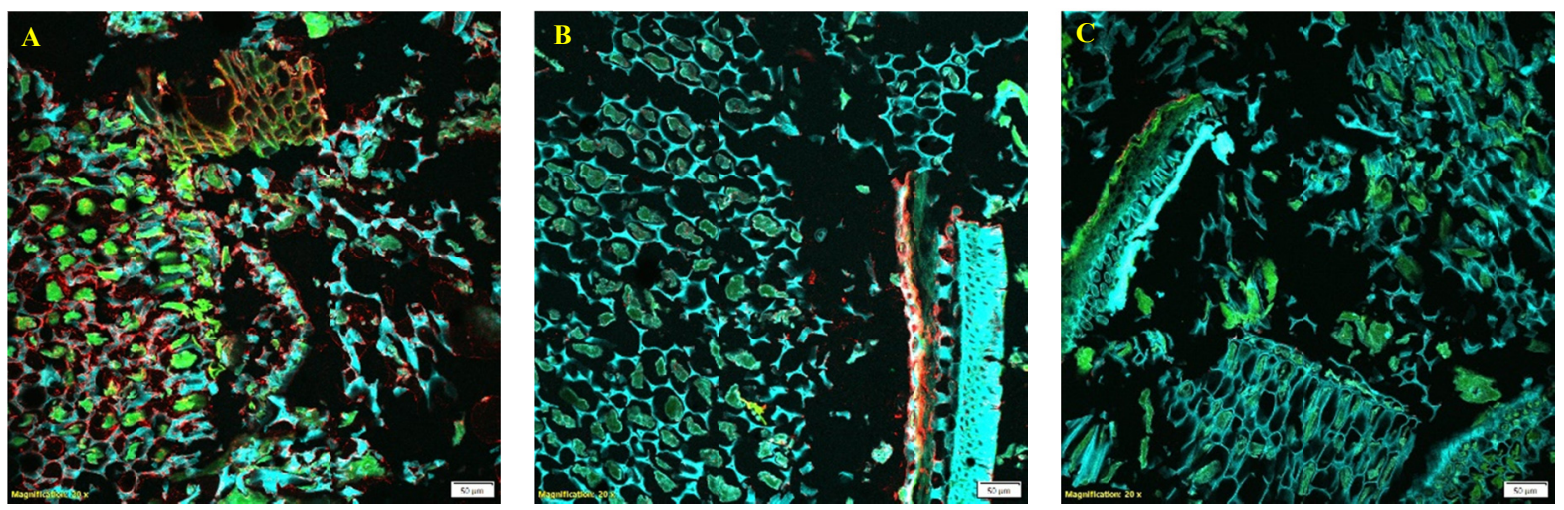

Figure 1. Specific b-mannan degradation visualized by immunolocalization with monoclonal antibody LM21

Note. SBM was incubated for 4 hours without (A) enzyme and with CTCzyme b-mannanase at recommended commercial dosage (B) and 10X recommended commercial dosage (C). In Figure 1A intact cell walls were visualized with immunolocalization using Ab LM21 to mannan (red signal). Calcofluor stain stained the cellulose visualized as blue color. Protein bodies were visualized as green bodies in the sample. Using commercial dosage of enzyme most of the mannan signal disappeared except in the aleurone layer-AL (Figure 1B), with no signal visible in the sample treated with 10X commercial dosage of enzyme (Figure 1C). A notable loosening and opening of the cell wall structure can be seen both with commercial (Figure 1B) and 10X commercial dosage of enzyme (Figure 1C) Bar $=50 \mathrm{~mm}$.

\subsection{Reducing Ends Assay}

An increase in the number of reducing sugars was seen from $0.05 \mathrm{mg} / \mathrm{mL}$ at $0 \mathrm{~min}$ to $0.12 \mathrm{mg} / \mathrm{mL}( \pm 0.02 \mathrm{mg} / \mathrm{L})$ at 120 mins $(\mathrm{P}<0.001)$.

\subsection{Oligomer Generation}

Two specific peaks were detected on the HPLC column which corresponded to mannobiose and mannotetraose each produced at $22.9 \mathrm{mg} / \mathrm{L}(3 \pm 0.2 \mathrm{mg} / \mathrm{L})$ and $398.8 \mathrm{mg} / \mathrm{L}( \pm 25.4 \mathrm{mg} / \mathrm{L})$. A statistical difference was detected in the degree of polymerization for both Mannobiose $(\mathrm{P}<0.001)$ and Mannotetraose $(\mathrm{P}<0.001)$.

\section{Discussion}

Microscopy of SBM shows intact cell walls despite the use of harsh conditions to remove the oil when SBM is processed (Figure 1A). Mannans are a complex set of hemicellulosic heteroglycans that are considered to have both storage and structural functions in cell walls (Liepman et al., 2007; Scheller \& Ulskov, 2010). Mannan polysaccharides have been proposed to cross-link cellulose and xyloglucan by means of hydrogen bonds (Schröder et al., 2009). These bonds can only be broken under in vitro conditions by use of high molarity solvents such as guanidinium thiocyanate or KOH (Schröder et al., 2009). Both cellulose and the hemicellulose xyloglucan are the main constituents of the NSP fraction in SBM (Pettersson \& Pontoppidan, 2012) whereas mannan is a minor fraction. Microscopy data clearly shows the close proximity of mannan to cellulose/xyloglucan in the cell walls (Figure 1A). With the solubilization of the mannan by CTCzyme, the b-mannanase containing product, there is loosening of the compact cell wall structure and a visible access to the protein within the cell walls can be seen with using both commercial as well as 10 times commercial dosages (Figures $1 \mathrm{~B}$ and $1 \mathrm{C}$ ). It is evident as seen with the microscopy pictures that CTCzyme at commercial dosage solubilizes the b-mannan present in SBM cell walls which most likely increases the availability of the protein to either exo- or endogenous proteases. It has been proposed that relatively low amounts of a specific polysaccharide in a given raw material, may show greater benefits if broken down by the relevant enzyme (Aftab \& Bedford, 2018). Our results confirm that although mannan is a minor component of SBM cell walls (Hsiao et al., 2006; Knudsen, 2014), it most likely has a huge impact on total digestibility by the animal (Ferreira et al., 2016; Kim et al., 2017; Park et al., 2019; Tewoldebrhan et al., 2017)

Mannan solubilization is important to partially destroy the cell wall architecture which is otherwise not destroyed during oil removal (Figure 1A). A small amount of b-mannan in SBM is also linked to b-conglycinin, the protein fraction in SBM (Kimura et al., 1997) but not much else is known and more work is warranted to understand 
how mannan solubilization by b-mannanases would affect the biological importance and bio-availability of b-conglycinin, a major protein found in SBM (Hidayat et al., 2011).

Due to the complex nature of the polysaccharides in plant cell walls, it is currently still debated as to whether single or multi-enzyme products containing debranching enzymes and targeting individual plant cell wall component are best suited to poultry rations. The rationale of using a multienzyme product to target specific distinct cell wall components within a given complex plant material seems to be an inaccurate approach according to some authors (Bedford, 2018; Aftab \& Bedford, 2018) due to inadequate scientific evidence. On the other hand Ravn et al. (2015) and Pedersen et al. (2017) visualized and highlighted the impact of specific enzyme components of a multicomponent enzyme product on SBM and canola meal in vitro but did not address the effect of a single enzyme on cell wall architecture. An increase in the amount of reducing sugars and formation of mannose oligomers during the course of the reaction in this study (Figure 2), indicates clearly the activity of the enzyme on SBM and its ability to solubilize mannan which is H-bonded to cellulose and xyloglucan (Schröder et al., 2009). This work also illustrates that mannan solubilization in SBM by CTCzyme the b-mannanase product alone is most likely sufficient to disrupt the cell wall architecture containing specific complex NSPs (Ravn et al., 2015), thereby alleviating the need for a multienzyme product.
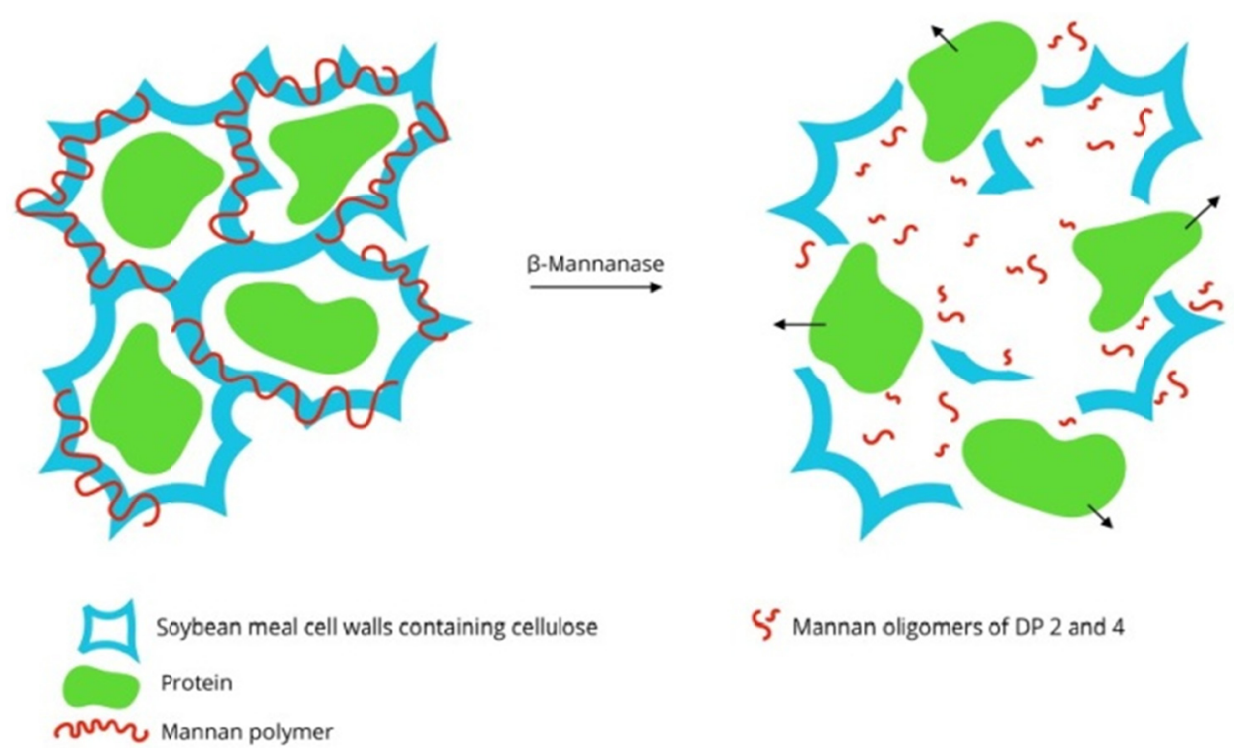

S Mannan oligomers of DP 2 and 4

Figure 2. A graphical illustration of what we propose is the effect of the b-mannanase on SBM as substrate based on the microscopy and wet chemistry data obtained; causing disruption of the cell walls in SBM by solubilizing mannan with production of mannan oligomers (MOS) of DP 2 and 4 having a prebiotic effect

The trend currently is to sell NSPases in a blend together with a very low concentration of fermentable oligosaccharides to prompt the training and development of a fiber degrading microbiome in the monogastric gut. The claim is a $2.5 \mathrm{pt}$ improvement in performance with the product as compared to a given NSPase only (Cordero et al., 2019). A plausible explanation for the addition of fermentable oligosaccharides could be that most NSPases, although effective, take a long time to work in the animal gut and are not be able to generate potent oligomers in time for training and development of a fiber-degrading microbiome. Thus, real enzyme effects may not be able to be translated within the lifespan of the animal. A single enzyme works better compared to multi-enzyme blends most likely due to their relatively higher concentration in a product (O'Neill \& Dos Santos, 2013). Multi-enzyme products may have low concentrations of each of the relevant enzymes thereby not being able to effectively breakdown the bridges/links present between the polysaccharides present in the cell wall matrix. One cannot assign a specific enzyme in a multienzyme product as being responsible for the animal performance and understanding whether the enzymes work additively, synergistically, or even sub additively is a challenge (Menezes-Blackburn \& Greiner, 2015).

In this work, using commercial dosages of enzyme, cell wall disintegration was visible, most likely making components such as proteins more available for endogenous proteases. Peer reviewed papers using microscopy as a tool to visualize enzyme action in vitro published in recent years have shown that it is necessary to use 900 
times commercial dosage of an NSPase (Ravn et al., 2016) and 100 and 1000 times commercial dosage to measure fiber solubilization (Pedersen et al., 2017) and to visualize enzyme efficacy using microscopy. The use of such high amounts may most likely indicate that the concentration of relevant enzyme/s in the NSPase product are very low and very high dosages are needed to show in vitro efficacy or the enzymes are acting sub additively. The in vitro data in this paper shows that using commercial dosage of b-mannanase product CTCzyme was sufficient to solubilize mannan.

An increase in reducing ends of sugars as well generation of mannose oligomers were measured in this study. The commercial prebiotic MOS-containing product Salmosan ${ }^{\circledR}$ S- $\beta$ GM (produced from carob and guar bean mannan hydrolyses) protected epithelial barrier function in a Caco-2 cell model disrupted by Salmonella enteritidis and had the ability to agglutinate the same (Brufau et al., 2016). MOS increased Bacteroidetes proliferation (Teng \& Kim, 2018); L. salivarius was shown to be most effective against Salmonella colonisation and L. crispatus is effective against both Salmonella and E. coli (Teng \& Kim, 2018). Supplementing broiler diets with MOS resulted in a reduction in coccidiosis lesions caused by Eimeria species (Elmusharaf et al., 2007) due to improved immune function and increased their growth performance as well (Chand et al., 2016). Supplementation of $0.2 \%$ dietary MOS to broilers significantly reduced E. coli profiles in the caecum and ileum of birds (Chacher et al., 2017). MOS having a degree of polymerization $\leq 5$ are stated to have powerful prebiotic and butyrogenic effects (Tiwari et al., 2020). In vitro assays measuring MOS in this work showed the generation of MOS having DP of 2 and 4 after enzyme reaction on SBM, indicating the ability of the b-mannanase to produce oligomers having prebiotic potential.

The irrefutable conclusion of the efficacy of a feed enzyme is of course proof of improved performance in the animal. In vivo data showed that supplementing a corn-soy diet with CTCzyme in a broiler trial increased the apparent metabolizable energy (AME) and apparent metabolizable energy corrected for nitrogen (AMEn) of diets by 4.6 and $5.0 \%$ (Kong et al., 2011). In the same way, using suboptimal nutrient levels in a broiler trial Ferreira et al. (2016) showed an improved AMEn of $1.5 \%$ with the inclusion of CTCzyme. With supplementation of CTCzyme $\beta$-mannanase in a low-energy and low-protein diet, laying hens were able to maintain similar production performance when compared to a high-energy and high-protein diet during early and late egg production (Zheng et al., 2020). There was no inclusion of any low molecular weight fermentable oligosaccharides in the above mentioned in vivo work besides the enzyme as opposed to the work of Cordero et al. (2019) which included both enzyme and fermentable oligosaccharides (in the experiment: a xylanase and xylan oligosaccharides). This suggests the ability of the b-mannanase product to solubilize mannans creating bioactive potent oligosaccharides even early in the digestion process in the animal gut within its life span, thereby alleviating the need for addition of further fermentable oligosaccharides in the product. Further work to test the prebiotic effect of the generated mannose oligosaccharides in vitro as well as inclusion of low molecular weight fermentable oligosaccharides in vivo needs to be conducted.

Based on our in vitro data in this paper, and published in vivo data (Kong et al., 2011; Mussini et al., 2011, Zheng et al., 2020) we can confirm the two modes of action of CTCzyme as an NSPase: (1) Solubilization of mannan in the cells walls to loosen and destroy the compact cell wall architecture thereby making the protein more bioavailable, and (2) Release of mannose oligomers considered to have prebiotic functions for improving gut health and integrity.

\section{References}

Aftab, U., \& Bedford, M. R. (2018). The Use of NSP Enzymes in poultry Nutrition: Myths and Realities. Worlds Poultry Science Journal, 74(June), 1-10. https://doi.org/10.1017/S0043933918000272

Bedford, M. R. (2018). The evolution and application of enzymes in the animal feed industry: The role of data interpretation. British Poultry Science, 59(5), 486-493. https://doi.org/10.1080/00071668.2018.1484074

Brufau, M. T., Campo-Sabariz, J., Bou, R., Carne, S., Brufau, J., Vila, B., ... Martin-Venegas, R. (2016). Salmosan, a,b-Galactomannan-Rich Product, Protects Epithelial Barrier Function in Caco-2 Cells Infected by Salmonella enterica Serovar Enteritidis. Journal of Nutrition, 146, 1492-1498. https://doi.org/10.3945/ jn. 116.232546

Chacher, M. F. A., Kamran, Z., Ahsan, U., Ahmad, S., Koutoulis, K. C., Qutab Ud Din, H. G., \& Cengiz, O. (2017). Use of mannan oligosaccharide in broiler diets: An overview of underlying mechanisms. Worlds Poultry Science Journal, 73, 831-844. https://doi.org/10.1017/S0043933917000757

Chand, N., Faheem, H., Khan, R. U., Qureshi, M. S., Alhidary, I. A., \& Abudabos, A. M. (2016). Anticoccidial Effect of Mananoligosacharide against Experimentally Induced Coccidiosis in Broiler. Environmental 
Science and Pollution Research International, 23(14), 14414-14421. https://doi.org/10.1007/s11356-016$6600-\mathrm{x}$

Cordero, C., Kim, J. C, Whenham, N., Masey-O’Neill, H., Srinongkote, S., \& González-Ortiz, G. (2019). Xylanase and fermentable xylo-oligosaccharides improve performance in grower-finisher pigs fed a corn-soybean meal-based diet. Journal of Animal Science, 97, 91-92. https://doi.org/10.1093/jas/skz122.166

Elmusharaf, M. A., Peek, H. W., Nollet, L., \& Beynen, A. C. (2007). The effect of an in-feed mannanoligosaccharide preparation (MOS) on a coccidiosis infection in broilers. Animal Feed Science and Technology, 134, 347-354. https://doi.org/10.1016/j.anifeedsci.2006.11.022

Ferrandis, V. M., Trudeau, M. P., Hung, Y. T., Zeng, Z., Urriola, P. E., Shurson, G. C., \& Saqui-Salces, M. (2018). Dietary fiber sources and non-starch polysaccharide-degrading enzymes modify mucin expression and the immune profile of the swine ileum. PLOS ONE, 13(11), e0207196. https://doi.org/10.1371/journal. pone.0207196

Ferreira, H. C., Hannas, M. I., Albino, L. F. T., Rostagno, H. S., Neme, R., Faria B. D., ... Rennó, L. N. (2016). Effect of the addition of $\beta$-mannanase on the performance, metabolizable energy, amino acid digestibility coefficients, and immune functions of broilers fed different nutritional levels. Poultry Science, 95(8), 1848-1857. https://doi.org/10.3382/ps/pew076

Garriga, M., Almaraz, M., \& Marchiaro, A. (2017). Determination of Reducing Sugars in Extracts of Undaria innatifida (harvey) Algae by UV-visible spectrophotometry (DNS method). Actas de Ingeniería, 3, $173-179$.

Herrera-Ubaldo, H., \& De Folter, S. (2018). Exploring Cell Wall Composition and Modifications During the Development of the Gynoecium Medial Domain in Arabidopsis. Frontiers in Plant Science, 9, 1-11. https://doi.org/10.3389/fpls.2018.00454

Hidayat, M., Sujatnonugraha, M., Sutadipura, N., \& Setiawan. A. F. (2011). $\beta$-Conglycinin Content Obtained from Two Soybean Varieties Using Different Preparation and Extraction Methods. HAYATI Journal of Bioscience, 18(1), 37-42. https://doi. org/10.4308/hjb.18.1.37

Hsiao, H. Y., Anderson, D. M., \& Dale, N. M. (2006). Levels of $\beta$-Mannan in Soybean Meal. Poultry Science, 85(8), 1430-1432. https://doi.org/10.1093/ps/85.8.1430

Kim, J. S., Ingale, S. L., Hosseindoust, A. R., Lee, S. H., Lee, J. H., \& Chae, B. J. (2017). Effects of mannan level and b-mannanase supplementation on growth performance, apparent total tract digestibility and blood metabolites of growing pigs. Animal, 11(2), 202-208. https://doi.org/10.1017/S1751731116001385

Kimura, Y., Ohno, A., \& Takagi, S. (1997). Structural analysis of N-glycans of storage glycoproteins in soybean (Glycine max L.) seed. Bioscience Biotechnology and Biochemistry, 61, 1866-1871. https://doi.org/10.1271/ bbb.61.1866

Knudsen, K. E. B. (2014). Fiber and nonstarch polysaccharide content and variation in common crops used in broiler diets. Poultry Science, 93(9), 2380-2393. https://doi.org/10.3382/ps.2014-03902

Kong, C., Lee, J. H., \& Adeola, O. (2011). Supplementation of B-mannanase to starter and grower diets for broilers. Canadian Journal of Animal Science, 91, 389-397. https://doi.org/10.4141/cjas10066

Lan, R., Li, T., \& Kim, I. (2017). Effects of xylanase supplementation on growth performance, nutrient digestibility, blood parameters, fecal microbiota, fecal score and fecal noxious gas emission of weaning pigs fed corn-soybean meal-based diet. Animal Science Journal, 88(9), 1398-1405. https://doi.org/10.1111/ asj.12771

Le, D. M., Fojan, P., Azem, E., Pettersson, D., \& Pedersen, N. R. (2013). Visualization of the anticaging effect of Ronozyme WX xylanase on wheat substrates. Cereal Chemistry, 90(5), 439-444. https://doi.org/ 10.1094/CCHEM-10-12-0130-R

Liepman, A. H., Nairn, C. J., Willats, W. G. T., Sørensen, I., Roberts, A. W., \& Keegstra, K. (2007). Functional genomic analysis supports conservation of function among cellulose synthase-like a gene family members and suggests diverse roles of mannans in plants. Plant Physiology, 143(4), 1881-1893. https://doi.org/ 10.1104/pp.106.093989

Marcus, S. E., Blake, A. W., Benians, T. A. S., Lee, K. J. D., Poyser, C., Donaldson, L., ... Knox, J. P. (2010). Restricted Access of Proteins to Mannan Polysaccharides in Intact Plant Cell Walls. The Plant Journal, 64, 191-203. https://doi.org/10.1111/j.1365-313X.2010.04319.x 
Mehri, M., Adibmoradi, M., Samie, A., \& Shivazad, M. (2019). Effects of beta-Mannanase on broiler performance, gut morphology and immune system. African Journal Biotechnolology, 9, 6221-6228.

Menezes-Blackburn, D., \& Greiner, R. (2015). Enzymes Used in Animal Feed: Leading Technologies and Forthcoming Developments. In G. Cirillo, U. Gianfranco Spizzirri, \& F. Lemma (Eds.), Functional Polymers in Food Science (pp. 47-73). Scrivener Publishing LLC. https://doi.org/10.1002/97811191 08580.ch4

Miller, G. (1959). Use of Dinitrosalicylic Acid Reagent for Determination of Reducing Sugar. Analytical Chemistry, 31, 426-428. https://doi.org/10.1021/ac60147a030

Moreira, L. R. S., \& Filho, E. X. F. (2008). An Overview of Mannan Structure and Mannan-degrading Enzyme Systems. Applied Microbiology and Biotechnology, 79(2), 165-178. https://doi.org/10.1007/s00253-0081423-4

Mussini, F. J., Coto, C. A., Goodgame, S. D., Lu, C., Karimi, A. J., Lee, J. H., \& Waldroup, P. W. (2011). Effect of B-Mannanase on Broiler Performance and Dry Matter Output Using Corn-Soybean Meal Based Diets. International Journal Poultry Science, 10(10), 778-781. https://doi.org/10.3923/ijps.2011.778.781

O’Neill, H. M., \& Dos Santos, T. (2013). Exploring the challenge of single vs multi-enzyme dosing comparisons. Grain and Feed Milling Technology (p. 37). Perendale Publishers Limited.

Park, J., Jung, S., \& Carey, J. B. (2019). Effects of a Commercial Beta-Mannanase Product on Growth Performance, Intestinal Histomorphology, Bone and Body Composition, and Amino Acid Digestibility in White Pekin Ducks. Journal of Applied Poultry Research, 28(1), 63-71. https://doi.org/10.3382/japr/pfy016

Pedersen, N. R., Ravn, J. L., \& Pettersson, D. (2017). A Multienzyme NSP Product Solubilises and Degrades NSP Structures in Canola and Mediates Protein Solubilisation and Degradation in vitro. Animal Feed Science and Technololgy, 234, 244-252. https://doi.org/10.1016/j.anifeedsci.2017.09.015

Pettersson, D., \& Pontoppidan, K. (2013). Soybean Meal and the Potential for Upgrading Its Feeding Value by Enzyme Supplementation. In H. A. El-Shemy (Eds.), Soybean-Bio-active Compounds (Chapter 13). In Tech. https://doi.org/10.5772/52607

Ravn, J. L., Martens, H. J., Pettersson, D., \& Pedersen, N. R. (2015). Enzymatic Solubilisation and Degradation of Soybean Fibre Demonstrated by Viscosity, Fibre Analysis and Microscopy. Journal of Agricultural Science, 7(9), 1-13. https://doi.org/10.5539/jas.v7n9p1

Ravn, J. L., Martens, H. J., Pettersson, D., \& Pedersen, N. R. (2016). A Commercial GH 11 Xylanase Mediates Xylan Solubilisation and Degradation in Wheat, Rye and Barley as Demonstrated by Microscopy Techniques and Wet Chemistry Methods. Animal Feed Science and Technolology, 219, $216-225$. https://doi.org/10.1016/j.anifeedsci.2016.06.020

Scheller, H. V., \& Ulvskov, P. (2010). Hemicelluloses. Annual Review Plant Biology, 61, $263-289$. https://doi.org/10.1146/annurev-arplant-042809-112315

Schröder, R., Atkinson, R. G., \& Redgwell, R. J. (2009). Re - interpreting the Role of Endo- $\beta$-mannanases as Mannan Endotransglycosylase/hydrolases in the Plant Cell Wall. Annals of Botany, 104, 197-204. https://doi.org/10.1093/aob/mcp120

Teng P. Y., \& Kim, W. K. (2018). Review: Roles of prebiotics in intestinal ecosystem of broilers. Frontiers in Veterinary Science, 5, 245. https://doi.org/10.3389/fvets.2018.00245

Tervila-Wilo, A., Parkkonen, T., Morgan, A., Hopeakoski-Nurminen, M., Poutanen, K., Heikkinen, P., \& Autio, K. (1996). In vitro Digestion of Wheat Microstructure with Xylanase and Cellulase from Trichoderma Reesei. Journal of Cereal Science, 24, 215-225. https://doi.org/10.1006/jcrs.1996.005

Tewoldebrhan, T. A., Appuhamy, J. A. D. R. N., Lee, J. J., Niu, M., Seo, S., Jeong, S., \& Kebreab, E. (2017). Exogenous $\beta$-mannanase Improves Feed Conversion Efficiency and Reduces Somatic Cell Count in Dairy Cattle. Journal of Dairy Science, 100(1), 244-252. https://doi.org/10.3168/jds.2016-11017

Tiwari, U. P., Stephen, A., Fleming, S. A., Rasheed, M. S. A., Jha, R., \& Dilger, R. N. (2020). The role of oligosaccharides and polysaccharides of xylan and mannan in gut health of monogastric animals. Journal of Nutrition Science, 9(21), 1-9. https://doi.org/10.1017/jns.2020.14

Zheng, L., Cho, S. H., Kang, C. W., Lee, K. W., Kim, K. E., \& An, B. K. (2020). Effects of $\beta$-mannanase on Egg Production Performance, Egg Quality, Intestinal Microbiota, Viscosity, and Ammonia Concentration in Laying Hens. Brazilian Journal of Poultry Science, 22(1). https://doi.org/10.1590/1806-9061-2019-1180 


\section{Copyrights}

Copyright for this article is retained by the author(s), with first publication rights granted to the journal.

This is an open-access article distributed under the terms and conditions of the Creative Commons Attribution license (http://creativecommons.org/licenses/by/4.0/). 